\title{
Adaptation Measuring Instrument Keyrsey Temperament Sorter
}

\author{
Indriyati Eko Purwaningsih ${ }^{1}$, Sri Adi Widodo ${ }^{1}$, Esti Harini ${ }^{1}$, Betty Kusumaningrum ${ }^{1}$, Flora \\ Grace Putrianti ${ }^{1}$, Mahmudah Titi Muanifah ${ }^{1}$ \\ \{ indriyati@ustjogja.ac.id, sriadi@ustjogja.ac.id, estiharini@ustjogja.ac.id, \\ betty.kusumaningrum@ustjogja.ac.id,flora@ustjogja.ac.id,mahmudah@ustjogja.ac.id\}
}

${ }^{1}$ Universitas Sarjanawiyata Tamansiswa, Yogyakarta, Indonesia ${ }^{1}$

\begin{abstract}
The purpose of this research is to adapt the personality measurement tool based on temperament that has been made by David Keirsey. The research method used is nonexperimental quantitative research with a measuring instrument adaptation research design. The adaptation process carried out in this study consisted of the study phase, the language transfer stage, and the empirical stage. The first stage aims to obtain information about key personality theory. The second stage is carried out with the forward-backward translation technique. The third stage was carried out by means of testing a measuring instrument for Student in "Universitas X" Yogyakarta, which was taken by cluster random sampling. The results show that a good measuring instrument is reliable because it has reached a reliability index of more than 0.800 for each preference. So that this KTS instrument has shown good validity and can be used to reveal the personality of students with the age range of $17-20$ years
\end{abstract}

Keywords: Measurement, Keirsey Temperament Sorter, Adaptation

\section{Introduction}

Personality is a person's behavior that is dynamic and is in him and used to adapt to the environment. Usually personality is used to classify humans. This is because personality has characteristics, characteristics, styles or traits that are typically associated with individual self. So that it can be said that personality comes from the formations we receive from the environment, such as the formation of the family in our childhood and also the innate that was brought from birth.

Personality comes from the word persona which means mask or mask, meaning what appears by birth does not always describe the real or in his mind [1], [2], personality is all the patterns of individual behavior and habits that are gathered in him and used to react and adjust to all stimuli from both inside and outside [3]. This pattern of behavior and habits is a functional unit that is typical of a person. This personality development is dynamic, meaning that as long as individuals are still knowledgeable and want to learn and add experience and skills, they will be more mature and steady in their personality. 
Human classification based on certain criteria is very difficult. The problem lies in heterogeneity and the uniqueness of human nature. There is no one human being who can be considered to have the same nature, then grouped according to that trait. In addition, humans are dynamic and change according to learning outcomes and environmental conditions. Even though he is a twin, it is very difficult to place a personality type. Science can only approach so that some similar features are grouped into several personality groups. Because personality has characteristics, characteristics, style or traits that are typically associated with individual self. So that it can be said that personality comes from the formations we receive from the environment, such as the formation of the family in our childhood and also the innate that was brought from birth.

Personality explains the differences in individual patterns of behavior with other individuals. Even though an individual is born twin, but a person's twin behavior must be different. These twins are only the same in physical appearance while behavior and personality will be different. The personality pattern that each individual has an impact on the learning process that will be used by the teacher. By knowing the personality of the students at least has three benefits for educators, namely helping the teacher in giving instructions to various students, educators can help students so that learning can be more effective and can respect the surrounding environment, especially with other individuals around them [4].

There are many ways to group an individual based on his personality. Among them are personality classification based on Myer-Brigs and Keirsey based classification. David Keirsey, divides personality based on temperament namely Extraversion or Introversion, Sensing or Intuition, Thinking or Feeling, and Judgment or Perception [5], [6]. Likewise, Myer-Brigs classifies personality based on these four preferences. The difference lies in the number of personality groups, if Keirsey becomes 4 types while for Myer-Brigs it becomes 16 types.

To find out someone's personality based on temperament Keirsey, a test tool called KTS is needed. This original version uses the English language and the background used to compile the KTS using the background of the country. To find out someone's personality (in Yogyakarta for example) a test tool is needed that must be adapted and adapted to the characteristics (in Yogyakarta for example) of individuals first.

In this regard, this study aims to adapt the personality instrument from Keirsey. This adaptation aims to create instruments that are adapted to environmental characteristics in the city of Yogyakarta and its surroundings

\section{Method}

The research method used is non-experimental quantitavive research [7], [8] with a measurement tool adaptation research design. The method used with a descriptive approach that gives a description of psychometric properties of measurement instruments is reliability and validity. This study aims to adapt the Keirsey Temperament Sorter (KTS) measuring instrument. This KTS measuring tool created by Kersey is a scale in the form of choosing from the two choices provided [5].

The adaptation process generally consists of the preliminary study, the language transfer stage, the empirical stage, and the restandarization stage (Pratiwi, Agustiani, \& N, 2017). In this study, the researcher carried out the adaptation process only to the empirical stage of ensuring the psychometric equality of adapted measuring instruments. 
In the first phase or stage of the study aims to obtain information about the theory of personality Keirsey namely Guardian, Artisan, Idealist and Rationalist, and the theory of adaptation of psychological measurement tools so that there are guidelines in arranging adaptation of psychological measuring instruments. The second stage or the language transfer stage, at this stage it is necessary to transfer the language by using the forward-backward translation technique. The third stage or empirical stage is done by testing the measuring instrument. Tests for measuring instruments were carried out on research subjects to see the reliability and validity of adapted measuring instruments. The selection of samples for the testing of measuring instruments using cluster sampling technique with 196 student "Universitas $\mathrm{X}$ " in Yogyakarta to first trial test and 105 student "Universitas X" in Yogyakarta to second trial test.

\section{Results and Discussion}

\subsection{Preliminary Study Phase}

At this stage researchers dig up as much information as possible about the personality type of keyrsey. Similar to the personality classification of Myer-Briggs, the classification of personality types from Keirsey is based on four preferences, namely Extraversion or Introversion, Sensing or Intuition, Thinking or Feeling, and Judgment or Perception [5], [6]. The difference between the personality of Myer and Briggs and Keirsey lies in the type formed from the four preferences. If Myer and Briggs of the four preferences become 16 personality types, but for Keirsey is formed into four personality types namely Guardian, artisan, idealist and rationalist.

Classification of personality into four types is based on the idea that there are differences that can be seen from someone through behavior. A person's behavior is a reflection of what is seen from what the person thinks and feels. To find out a student's thinking about the work on a particular question, of course it is not seen from his behavior, but specifically from the work of the students. To be able to find out the thoughts of a student, one of them can be by inviting students to discuss with the teacher, so that students will say what is in their thoughts when working on certain questions.

When someone touches an object, pays attention to the game of football, feels food, etc. where humans use their senses, then the human will use observant properties. When humans reflect and show concern for what is happening in their brains, then humans will be instinctive. Keirsey believes that humans cannot be observant at the same time as at the same time introspective, and the tendency towards one of them will have a direct effect on their behavior.

A person who is more observant will be more "grounded" and more concrete in looking at the world, and aims to pay more attention to practical events, and immediate relationships. An observant will assume that everything that is important is born from what is experienced, whether the experience is then ascertained as judging, or the experience is left open as perceiving, in other words he will use the functions in his life., both through judging and perceiving. Keirsey named this concrete person as a guardian, if the person is sensing and judging, and Artisan if the person is sensing and perceiving.

Someone who is more instinctive will put the brain above everything and be more abstract in looking at the world, and focusing on global events. Because it is introspective, it is very important for him to form concepts within him. The concept that is formed can come from objective reasoning and not emotion-based (thinking), or concepts that are formed based on 
feelings or emotions (feeling). Keirsey calls this instinctive person a rational if the person is intuitive and thinking, and idealist if the person is intuitive and feeling.

The idealist personality type is more prominent in intuitive and felling. This personality type has a passionate temperament, concerned with personal growth and development. Idealist types try to find out who they are and how they can be the best. Idealist types are naturally interested in working with others, both in collaboration in education, counseling, or social services. The characteristics or characteristics of idealist personality types, including being very enthusiastic, believing in their feelings, liking a romantic atmosphere, seeking their identity, upholding kinship / friendship, kindness and honesty, tend to give, believe, be spiritual, and focus on the purpose of life and human potential, making closeness with partners, parents, and being an inspirational leader. idealistic personality types are relatively rare, not up to 12 percent of the world's population. But the idealist ability is able to exert an influence that exceeds their number [5], [6].

The more prominent type of guardian is its sensing and judging. The characteristics or characteristics of the guardian personality type, including reliable, helpful to others, and diligent. A person with a guardian personality can be made a friend, someone who is full of responsibility, and has the character (soul) of a leader, the guardian has a tendency to be obedient, very careful, simple, and try to maintain the trust that has been given to him. The population of a person with guardian personality is between $40-45 \%$ of the total population in the world [5], [6].

Rationalist likes an explanation based on logic. They are able to capture abstractions and materials that require high intellectuality. After being given material by the teacher, rationalists usually seek additional material through reading books. Rationalist likes teachers who can provide additional assignments individually after giving material. In accepting material, rationalist likes teachers who explain other than the material, but also why or where it came from. The preferred field is usually science, mathematics, and philosophy, although it does not rule out the possibility of success in the area of interest. The most preferred way of learning is experimentation, discovery through exploration, and complex problem solving. This group tends to ignore the material that is deemed unnecessary or time-wasting, therefore, in each material giving, the teacher must be able to convince the interests of a material to another material. [5], [6].

Basically the type of artist likes change and is not resistant to stability. Artisan is always active in all circumstances and always wants to be the attention of everyone, both teachers and friends. The preferred class form is a class with lots of demonstrations, discussions, presentations, because this type can show its abilities. Artisan will work hard when stimulated with a context. Everything wants to be done and known quickly, often even tends to be too hasty. Artisan will get bored quickly, if the teacher does not have a technique that changes in teaching. [5], [6].

These four preferences used by Keirsey, Myer and Briggs are used as guidelines for adapting this Keirsey personality type gauge. So the indicators used in the Keirsey personality gauge are Extrovert Vs Introvert (E Vs I), Sensing Vs Intuitive (N Vs S), Thinking vs. Feeling (T Vs F), and Judging Vs Perceiving (J Vs P).

\subsection{Translation Phase}

The original type personality classification instrument uses English and has 70 questions. The personality type classification instrument was taken from the book Understanding Me Me written by David Keirsey and Marylin Bates and Please Understand Me II written by David Keirsey. Personality type classification instrument or called the Keirsey Temperament Sorter (KTS) consists of 4 (four) preferences, these four preferences are Extrovert Vs Introvert (E Vs 
I), Sensing Vs Intuitive (N Vs S), Thinking vs. Feeling (T Vs F), and Judging vs. Perceiving (J Vs P) [5], [6].

The KTS was once translated and used to research high school students' profiles in solving problems of mathematical problems viewed from personality types [9], then this instrument was called the Yuwono version of KTS. Related to this, KTS veris Yuwono has advantages such as (1) the instrument has used Indonesian language, (2) the instrument has been validated by a psychologist, namely Uswah Wardiana, M.Psi. Yuwono's version of the KTS problem is the linguistic side, the results of many personality test results that are not adaptable in terms of language, and the Yuwono version of KTS has not been tested so it can be stated that the KTS is still weak because it does not have a reliability coefficient. In connection with these problems, it is necessary to adapt the KTS personality measuring instrument from the original version.

The language transfer stage is a process in which researchers translate English-language measuring instruments into Indonesian. The researcher uses the forward-backward translation technique with the help of a psychologist.

\subsection{Empiric Phase}

Validity is the accuracy and accuracy of measuring instruments. A measuring instrument can be said to be a valid measuring tool if the measuring instrument can measure what you want to measure precisely [10], [11]. In this case, validity and reliability is needed to measure whether or not a measuring instrument [12]. Validity is a measurement that really measures what we want to measure, while reliability is consistency or constancy in answering questions. Instruments with high reliability will produce the same results when measured again at other times on the same scale [13], [14].

Validity carried out by psychologists in this case is a psychologist. Interpretation of KTS instruments is given to psychologists and counselors to validate the contents. Validation results show the contents, KTS instruments can be concluded in good category. So that the KTS instrument can be tested on students.

The results of the KTS trial conducted on 196 students aimed to determine the reliability of the KTS test equipment. The trial of this test tool was given to Sarjanawiyata Tamansiswa University students as many as 108 students. The test results of the KTS test were the reliability index for preference E-I was 0.672 , the reliability index for S-N preference was 0.783 , the reliability index for T-F preference was 0.766 , and the reliability index for J-P preference was 0.769 .

An instrument is expected to have a reliability index of 0.900 , this is so that the predictions and diagnoses to be carried out do not slide. But the reliability index of less than 0.900 is still considered significant in certain measurement cases [4] as in personality instruments that are still allowed to use a reliability index of 0.800 [15]. Based on this, KTS personality test kits still need improvement, especially in terms of language, because there is a possibility of bias subjects in understanding items on the KTS instrument. After the KTS instrument was improved, the instrument was tested again in the hope that the reliability index would be more than 0,800 .

The second KTS trial involved 105 students. The calculation results obtained that the reliability index for preference E-I was 0.820 , the reliability index for S-N preference was 0.865 , the reliability index for T-F preference was 0.832 , and the reliability index for J-P preference was 0.856 . Based on the results of the KTS instrument trial, it can be concluded that the KTS personality test results from the second development have fulfilled the requirements for grouping keyrsey personality. 


\section{Conclusion}

A good measuring instrument is reliable, valid, standard, economical and practical. KTS instrument reliability has reached more than 0,800 for each preference. So that this KTS instrument has shown good validity and can be used to reveal the personality of students with the age range of $17-20$ years.

\section{References}

[1] G. Ramadhani, D. Irianto, and N. A. Setiyanto, "Rancang Bangun Sistem Pakar Untuk Mengetahui Karakteristik Kepribadian Pada Anak Dengan Menggunakan Metode Forward Chaining Berbasis Web," pp. 1-18, 2009.

[2] M. Mauss, "A category of the human mind: the notion of person; the notion of self.," in The category of the person: Anthropology, philosophy, history, 1985, p. 2018.

[3] I. Abadi, "Pengembangan Sistem Pendeteksi Kepribadian Manusia Dengan Menggunakan Konsep Jendela Johari,” J. Inf., vol. 4, no. 1, pp. 12-21, 2011.

[4] J. Periantalo and S. Azwar, "Pengembangan Skala Kepribadian Siswa SMA Dari Tipologi Kepribadian Jung Dan Myers-Briggs,” J. Sains Sosio Hum., vol. 1, no. 2, pp. 191-207, 2017.

[5] D. Keirsey and M. Bates, Please Understand Me I. California: Prometheus Nemesis Books, 1984.

[6] D. Keirsey, Please Understand Me II: Temperament Character Intelligence. California: Prometheus Nemesis Books, 1998.

[7] B. Johnson, "Toward a New Classification of Nonexperimental Quantitative Research," Educ. Res., vol. 30, no. 2, pp. 3-13, 2001.

[8] J. W. Creswell, Educational Research: Planning, Conducting and Evaluating Quantitative and Qualitative Research. London: Pearson, 2012.

[9] A. Yuwono, "Profil Siswa SMA Dalam Memecahkan Masalah Masalah Matematika Ditinjau Dari Tipe Kepribadian,” Universitas Sebelas Maret, 2010.

[10] C. L. Kimberlin and A. G. Winterstein, "Validity and reliability of measurement instruments used in research," Am. J. Heal. Pharm., vol. 65, no. 23, pp. 2276-2284, 2008.

[11] K. Krippendorff, "Reliability," Int. Encycl. Commun., 2008.

[12] Z. Matodang, "Validits Dan Reliabilitas Suatu Instrumen Penelitian," J. Tabularasa PPS UNIMED, vol. 6, no. 1, pp. 87-97, 2009.

[13] T. L. Milfont and J. Duckitt, "The environmental attitudes inventory: A valid and reliable measure to assess the structure of environmental attitudes," J. Environ. Psychol., vol. 30, no. 1, pp. 80-94, 2010.

[14] M. J. Allen and W. M. Yen, Introduction to Measurement. Waveland Press, 2001.

[15] S. Urbina, Essentials of Psychological Testing. New Jersey: John Wiley \& Sons, Inc, 2004. 